\title{
Mortality of coke plant workers in the Netherlands
}

\author{
G M H Swaen, J J M Slangen, A Volovics, R B Hayes, T Scheffers, F Sturmans
}

\begin{abstract}
During the production of coke, large quantities of coke oven gas are emitted. People who work on the top or on the sides of coke ovens are exposed to this oven gas, which contains a range of carcinogenic chemicals. To investigate the cancer risks under these work conditions, a retrospective study was undertaken. In total 11399 former workers were enrolled in the study. Of these, 5639 had worked in the coke plant for at least six months between 1945 and 1969. The other 5740 had worked in another plant during the same period and formed a non-exposed group for comparison. The study group was followed up until 1984 for mortality. The causes of death were obtained from the Central Bureau of Statistics. Among the coke oven workers significantly higher death rates were found for lung cancer and non-malignant respiratory disease. Mortality in the byproduct section was similar to that expected. Among workers in the tar distillery the rate for lung cancer was higher than expected. The risk for gastric cancer and non-malignant respiratory disease among the workers of the coke shipping department was increased but the SMRs did not reach statistical significance. No data were collected about individual smoking habits or socioeconomic state of the study subjects and the possibility that the risk found could be attributed to these factors cannot be ruled out. It has been stated by other investigators, however, that the effect of not controlling for smoking tends to be modest.
\end{abstract}

Department of Occupational Medicine, University of Limburg, the Netherlands

G M H Swaen, J J M Slangen

Department of Epidemiology, University of Lim-

burg, the Netherlands

F Sturmans

Department of Biostatistics, University of Limburg, the Netherlands

A Volovics

4317 Saul Road, Kensington, MD, USA

R B Hayes

DSM Chemical Company, Geleen, the Netherlands

T Scheffers
The main use of coke is as fuel for blast furnaces to retrieve iron from iron ore. Recently the worldwide coke production has declined as a result of decreasing demands for products of the heavy iron and steel industry and also as a result of the use of other fuels. The worldwide production of coke in 1977 was estimated to be around 360 million tonnes. ${ }^{1}$ Coke is derived from bituminous coal by destructive heating in the absence of oxygen. ${ }^{2}$ After the oven is charged with coal particles from the top, the oven is heated for 20 hours at a temperature of $1100^{\circ} \mathrm{C}$. Then the doors on each side of the oven are removed and the coke is pushed out by machine into a quenching car. This is shunted to the quench tower where the hot coke is cooled with water. On the coke wharf the coke is allowed to cool down further. During the coking process large quantities of gas escape from the coal and are collected in mains. This coke oven gas is processed in the chemical department where a number of chemicals are extracted mainly by distillation processes.

Coal tar is separated out in the tar distillery. In the benzene plant the lighter fractions containing benzene, phenols, toluene, and other solvents are distilled. Several other installations are located in the chemical sector, mainly for the purpose of gas treatment, such as the sulphate plant, the $\mathrm{H}_{2} \mathrm{~S}$ plant and the generator gas plant. Several other departments are present mainly for maintenance and logistics purposes. These include maintenance shops, electrical engineering departments, personnel departments, and occupational health departments.

Occupational exposures of coke plant workers vary greatly from department to department and from job to job. In several countries air samples have been taken at the top and side of coke ovens. In these samples benz(a)pyrene concentrations have been determined. Table 1 presents these concentrations. In the Netherlands air samples close to coke ovens have been taken, but the fractions of benz(a)pyrene have not been determined.

Table 2 shows a schematic presentation of the production facilities of a coke plant and consequent chemical exposures. The main occupational exposure at the coke ovens is to coke oven gas. This contains several carcinogenic substances, such as benz(a)pyrene, chrysene, 2-naphtylamine, arsenic, and benzene. ${ }^{3}$ The carcinogenicity of coke oven 
Table 1 Benz (a)pyrene concentrations in air samples taken from top side of several coke ovens

\begin{tabular}{|c|c|c|c|}
\hline $\begin{array}{l}\text { Country } \\
\text { (year of publication) }\end{array}$ & Type of coke plant & $\begin{array}{l}\text { Lowest concentration } \\
\left(\mu \mathrm{g} / \mathrm{m}^{3}\right)\end{array}$ & $\begin{array}{l}\text { Highest concentration } \\
\left(\mu g / m^{3}\right)\end{array}$ \\
\hline $\begin{array}{l}\text { Soviet Union (1962) } \\
\text { Czechoslovakia (1971) }\end{array}$ & $\begin{array}{l}\text { Coke plant } \\
\text { Metallurgical coke plant } \\
\text { Coke plant }\end{array}$ & $\begin{array}{l}1 \cdot 3 \\
3 \cdot 0 \\
1 \cdot 0\end{array}$ & $\begin{array}{l}27 \cdot 4 \\
33 \cdot 0 \\
23 \cdot 1\end{array}$ \\
\hline $\begin{array}{l}\text { United States (1974) } \\
\text { Norway (1978) } \\
\text { Poland (1978) }\end{array}$ & $\begin{array}{l}\text { Coke plant } \\
\text { Coke plant } \\
\text { Old coke plant } \\
\text { After modernisation } \\
\text { Modern coke plant }\end{array}$ & $\begin{array}{c}1 \cdot 2 \\
8 \cdot 0 \\
20 \cdot 0 \\
0 \\
0\end{array}$ & $\begin{array}{r}15 \cdot 9 \\
135 \cdot 0 \\
282 \cdot 0 \\
6 \cdot 8 \\
27 \cdot 0\end{array}$ \\
\hline $\begin{array}{l}\text { West Germany (1982) } \\
\text { Sweden }(1982) \\
\text { England (1972) }\end{array}$ & $\begin{array}{l}\text { Coke plant } \\
\text { Coke plant } \\
\text { Coke plant }\end{array}$ & $\begin{array}{l}5 \cdot 0 \\
9 \cdot 4 \\
2 \cdot 1\end{array}$ & $\begin{array}{l}15 \cdot 5 \\
13 \cdot 5 \\
27 \cdot 3\end{array}$ \\
\hline
\end{tabular}

Table 2 Main production facilities and subsequent exposures in coke plants

\begin{tabular}{|c|c|}
\hline Facility & Chemical exposures \\
\hline Coke ovens & $\begin{array}{l}\text { Coke oven gas containing polycyclic } \\
\text { aromatic hydrocarbons }\end{array}$ \\
\hline Tar distillery & Coal tar, naphthalene, coke oven gas \\
\hline Benzene plant & $\begin{array}{l}\text { Benzene, toluene, xylene, } \mathrm{CS}_{2} \text {, coke } \\
\text { oven gas }\end{array}$ \\
\hline Sulphate plant & Ammonia, sulphuric acid, $\mathrm{H}_{2} \mathrm{~S}, \mathrm{HCN}$ \\
\hline $\mathrm{H}_{2} \mathrm{~S}$ plant & $\begin{array}{l}\text { Coal tar, coke oven gas, naphthalene, } \\
\mathrm{H}_{2} \mathrm{~S}, \mathrm{HCN}\end{array}$ \\
\hline Generator gas plant & Generator gas \\
\hline
\end{tabular}

emissions has been investigated experimentally, by topical application of dried coke oven main samples to mice. ${ }^{45}$ The incidence of skin papillomas and carcinomas was increased. Experimental inhalation also produced an increase in lung tumours in mice. ${ }^{67}$ The carcinogenic risk of coke oven emissions to man has recently been reviewed by the International Agency for Research on Cancer (IARC). ${ }^{8}$

Several epidemiological studies of coke oven workers have been carried out (table 3). Kennaway and Kennaway investigated deaths from lung cancer and laryngeal cancer that occurred between 1921 and 1938 in England and Wales. ${ }^{9}$ Occupation was shown on the death certificates. The investigators used national census data to calculate the expected number of deaths for a particular occupation in the general population. The number of deaths from lung cancer in the occupational group of coke oven workers was $2 \cdot 8$ times higher and from laryngeal cancer $2 \cdot 1$ times higher than expected. In another study Christian ${ }^{10}$ followed up a group of workers who had been employed at a coal gasification plant. The production process of coal gasification is similar to that of a coke plant. He found that mortality from lung cancer in the group was 24 times that of the general population. In the same year Reid and Buck ${ }^{11}$ reported the results of an epidemiological study of deaths that occurred among coke plant workers between 1949 and 1954. The causes of death were compared with causes of death for workers who had been employed in another company. They did not differ between the coke plant workers and the nonexposed workers. The design of this study is quite different from those generally applied in occupational studies, which makes it difficult to assess whether the design was appropriate.

In 1967 Japanese investigators reported the results of a retrospective cohort study of workers who had been employed at a coal gasification plant. ${ }^{12}$ This study was triggered by earlier case reports of deaths from lung cancer in Japanese coal gasification workers. ${ }^{13} \mathrm{~A}$ reference group of workers in the generator gas plant was also included. Both groups were followed up in a similar fashion. Causes of death were obtained from medical records in local hospitals. In the exposed population six workers of the coal gasification plant had died from lung cancer, compared to an expected number of $0 \cdot 18$. The risk of lung cancer increased with duration of exposure and remained high after exposure ceased. The quality of the medical data available for the exposed group was different from that for the non-exposed group, which may imply that the lung cancer cases in the exposed group were more likely to be diagnosed as such.

In 1972 Doll et al ${ }^{14}$ reported the results of a retrospective cohort study among coal gasification workers in Great Britain. A cohort of 4700 workers, all exposed on 1 September 1953, was followed up until 1965 . Only $0.5 \%$ of the cohort was lost to follow up. The workers were divided into three exposure groups and their death rates were compared with those for the general population. In the group with the highest exposure the risk for bladder cancer was 2.5 times that of the general population, scrotal and skin cancer was six times higher, and rates for lung cancer and mortality from bronchitis were also increased.

Sakabe et $a l^{15}$ studied the mortality patterns of 2200 pensioned coke plant workers in Japan between 1947 and 1973. The study comprised workers from 11 coke plants. The mortality patterns among these workers resembled those of the general population. If 
Table 3 Overview of results of epidemiological studies of coke oven workers and coal gasification workers conducted in other countries

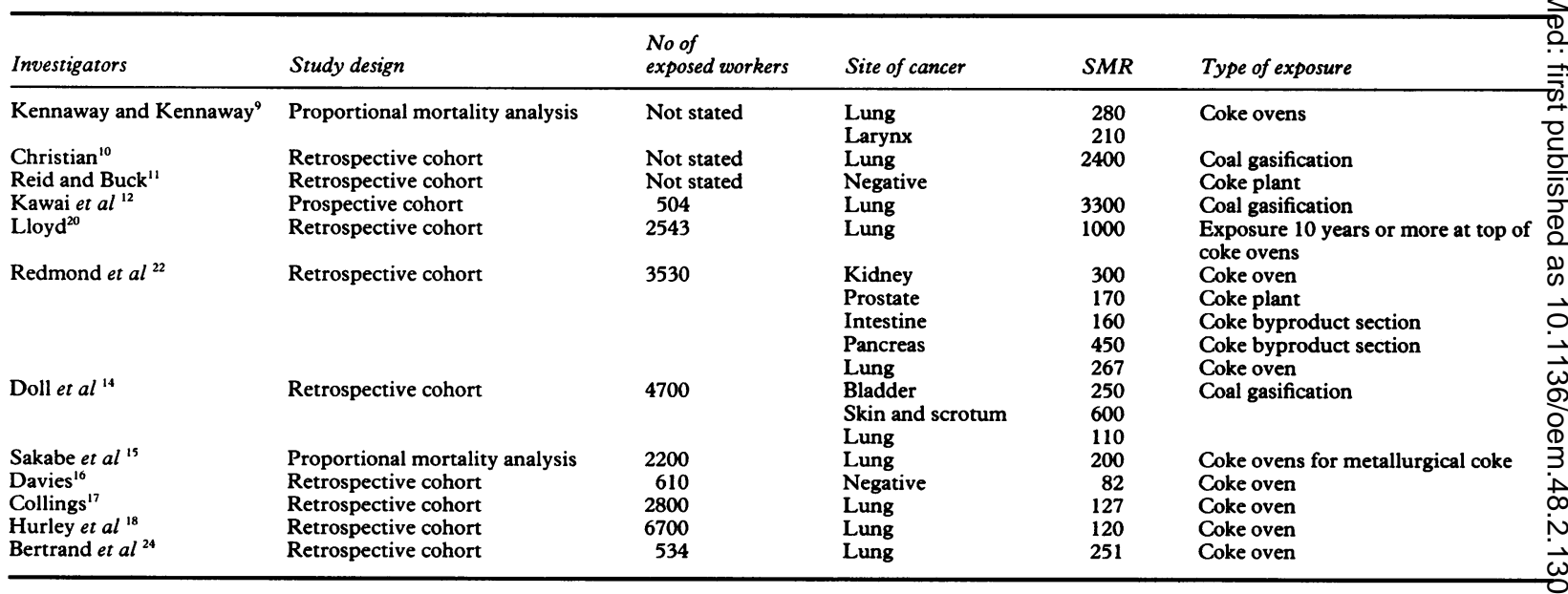

the cohort was restricted, however, to coke plants that were a part of a steel company, mortality from lung cancer was twice as high as expected.

Davies $^{16}$ followed up a cohort of 610 coke plant workers in Great Britain over a period of 11 years. The total mortality in this group was $15 \%$ lower than expected. No excess of mortality for cancer from any site was noted.

Under the commission of the European Community for Coal and Steel, Collings conducted an epidemiological study of 2800 workers of 14 British coke plants. ${ }^{17}$ All workers employed on 1 July 1967 were followed up until 1976. The cause-specific mortality in the cohort was compared with that of unskilled and semi-skilled personnel in Great Britain. Among coke oven workers who had been employed for five years or more a $27 \%$ increase in mortality from lung cancer was found. Later this study was expanded to 6767 coke oven workers and produced similar results. ${ }^{18}$

A study of coke plant workers has been carried out in the United States at the University of Pittsburgh. ${ }^{19-22}$ The population consisted of 58000 steel workers employed in 1953 . The workers were followed up until 1961 . The mortality of the coke oven workers was compared with that of steel workers. Redmond $e t a l^{2}$ expanded the size of the cohort and the period of follow up. Among the non-white coke oven workers the rates of lung cancer were twice as high as those of steel workers. Workers employed on top of the ovens experienced rates of lung cancer eight times as high as those of steel workers. Incidence of intestinal, kidney, pancreatic, and prostatic cancers was also increased among the coke oven workers. These results could not be confirmed in a later case-control study of lung cancer, ${ }^{23}$ a study restricted, however, to white men only.
Finally an epidemiological study of 534 coke oven workers was conducted in France on workers who had retired between 1963 and $1982 .{ }^{24}$ Mortality from cancer was 2.5 times higher than that for the general population of France. Mortality from lung cancer in the general population in the region in which the study was carried out, however, is significantly higher than that for the total population of France. This difference may account for a part of the increased risk of lung cancer in the study population. A second weak point was the collection of cases in the cohort. Causes of death were obtained from medical files, which may have resulted in a higher ascertainment rate in the exposed group than in the general population.

The specific aim of our study was to investigate if Dutch coke oven workers exposed to coke oven gas were also at higher risk for lung and other cancers.

\section{The three coke plants under investigation}

Much of the coal found in the Netherlands was of a bituminous type, not suitable for household purposes. To make mining of this bituminous coal profitable, it was decided to build large plants to produce coke. ${ }^{25}$ The first coke, from the coke plant $\mathrm{E}$ 1 , was produced in 1918. From the start much attention was given to gas production and the distillation of chemicals. Coke plant E 1 remained in production until 1945. Coke plant $M$ was one of the largest in Europe and began production in 1929. Because of poor maintenance during the second world war and other technical considerations coke plant $\mathrm{E} 1$ was replaced by a modern coke plant E $2 .^{26}$

As much of the profitably exploitable coal was nearly exhausted and because of the great natural gas resources that were discovered, it was decided to stop 
coalmining in the Netherlands. Consequently plants E 2 and $M$ were shut down in 1968. Based on descriptions we concluded that the hygienic conditions were best in plant $\mathrm{E} 2$, intermediate in plant $M$, and poorest in plant $\mathrm{E} 1$.

\section{Material and methods}

The study population consisted of 11399 male workers who were employed at the ovens of one of the coke plants or a particular nitrogen fixation plant for at least six months between 1945 and 1969, who held Dutch citizenship and who were living in the Netherlands. The workers included in the comparison group (nitrogen fixation plant) had been exposed to NOx fertiliser dust. The occupational history, name, and address of these 11399 male workers were available in the personnel files of the company. All 150000 files of past and present employees were screened to identify workers eligible for the study. From all 5659 workers employed at the coke plants for more than six months, information on the occupational history consisted of job and workplace and periods of work. The job classification scheme enabled the coding of every job mentioned in the files and included over 100 specific jobs. The list of workplaces also contained more than 100 different sites. The screening of the files and collecting of the occupational history was done by persons who were trained for this work and who were informed of the procedures to be followed.

The procedure of the follow up was similar for the exposed and the non-exposed group. Some eligible workers were still employed by the companies at the end of follow up. The files of the company's pension fund showed study subjects who were receiving retirement benefits at the end of follow up. Those still working and known pensioners were not entered into further follow up procedures. For the remaining subjects information about their vital state was requested at the municipal population registries. All population registries that were contacted participated in the study. For subjects that moved from one municipality to another, it was necessary to contact the population registry of the municipality to which the person had moved.

Information about the causes of death was received from the Central Bureau of Statistics. The various International Classification of Diseases (ICD) categories were converted to the ICD-ninth revision. All causes were grouped into seven main categories. The category "neoplasms" was divided into 28 anatomical sites. Table 4 shows the results of the follow up.

The statistical analysis consisted of a person-time analysis to correct for differences in age distribution, period of follow up and the fluctuation of background death rates. The person-time analysis was conducted
Table 4 Vital state of workers enrolled in coke plant study at 1 January 1984, the end of follow up

\begin{tabular}{|c|c|c|}
\hline & $\begin{array}{l}\text { Coke plant } \\
\text { workers } \\
\text { No }(\%)\end{array}$ & $\begin{array}{l}\text { Reference } \\
\text { group } \\
\text { No }(\%)\end{array}$ \\
\hline $\begin{array}{l}\text { Total No of workers in } \\
\text { the study } \\
\text { Died before } 1 \text { January } 1984\end{array}$ & $\begin{array}{l}5659(100) \\
1374(24 \cdot 3)\end{array}$ & $\begin{aligned} 5740 & (100) \\
893 & (15 \cdot 6)\end{aligned}$ \\
\hline $\begin{array}{l}\text { Emigrated before } \\
1 \text { January } 1984 \\
\text { Lost to follow up } \\
\text { Alive at } 1 \text { January } 1984\end{array}$ & $\begin{array}{rr}127 & (2 \cdot 2) \\
4 & (0 \cdot 1) \\
4154 & (73 \cdot 4)\end{array}$ & $\begin{array}{rr}137 & (2.4) \\
5 & (0.1) \\
4705 & (81.9)\end{array}$ \\
\hline
\end{tabular}

by the computer program designed by Peto. ${ }^{27}$ Expected numbers were calculated by applying the cause, age, and calendar time specific death rates of the total Dutch male population to the generated person-years of the exposed and non-exposed cohort. Two sided confidence limits $(95 \%)$ were calculated as proposed by Breslow and Day. ${ }^{28}$ Although a non-exposed working cohort was at hand, the basic comparison was with the cause specific mortality of the total Dutch male population. Because the individual causes of death are not at our disposal, it has not yet been possible to investigate dose response relations by means of statistical modelling. Negotiations are under way with the Central Bureau of Statistics to carry out further dose response analyses on the individual data under their supervision.

\section{Results}

In the reference group the total mortality was lower than expected (893 observed $v 993$ expected deaths; see table 5). This phenomenon of lower mortality in working populations has frequently been found in cohort studies and is called the healthy worker effect.

The total mortality of the exposed cohort of coke oven workers was higher than expected ( 520 observed $v 438$ expected deaths, standard mortality ratio $(S M R)=118 \cdot 7)$. This increase was statistically significant $(95 \%$ confidence interval $(95 \% \mathrm{CI})$ 106.5-127.0). Restricting the exposed cohort to those who had worked at the oldest plant (E 1) resulted in a higher SMR of $130 \cdot 7$ ( 180 observed $v$ 137.7 expected deaths), which was statistically significant ( $95 \%$ CI $112 \cdot 3-151 \cdot 3)$. The mortality risks of workers who had only worked at the E 2 or $M$ plants were less pronounced (SMRs of 112 (E 2) and 114 (M). Mortality from respiratory diseases was significantly higher than expected. The SMR for mortality from respiratory disease in the coke oven cohort was 166 (51 observed $v 30.8$ expected deaths, $95 \%$ CI 123.4 217.7), which was statistically significant. In the coke oven workers mortality from cancer of several sites was increased. This was so for lung cancer (SMR = $129,95 \%$ CI $99 \cdot 0-165 \cdot 5)$, gastric and small intestine cancer $(S M R=142,95 \%$ CI 91.0-211.4), and liver 
Table 5 Cause specific mortality in a cohort of plant workers and a cohort of non-exposed workers

\begin{tabular}{|c|c|c|c|c|c|c|}
\hline \multirow[b]{2}{*}{ Cause of death } & \multicolumn{2}{|c|}{ Non-exposed workers } & \multicolumn{2}{|c|}{ Coke oven workers } & \multicolumn{2}{|c|}{ Byproduct workers } \\
\hline & Observed No & $S M R$ & Observed No & $S M R$ & Observed No & $S M R$ \\
\hline \multicolumn{7}{|l|}{ Main categories: } \\
\hline Infectious diseases & 7 & 61 & 4 & 71 & 8 & 78 \\
\hline Neoplasms & 259 & $85^{\star}$ & 160 & $123^{\star}$ & 282 & 106 \\
\hline Circulatory system & 395 & 99 & 186 & 98 & 338 & 94 \\
\hline Respiratory system & 57 & 103 & 51 & $162^{\star}$ & 49 & 93 \\
\hline Digestive system & 19 & $57^{\star}$ & 18 & 124 & 23 & 78 \\
\hline Others & 61 & $60^{\star}$ & 48 & 109 & 68 & 75* \\
\hline External causes & 65 & $75^{\star}$ & 30 & 131 & 56 & 79 \\
\hline Unknown & 30 & - & 23 & - & 30 & - \\
\hline \multicolumn{7}{|l|}{ Neoplasms: } \\
\hline Mouth and pharynx & 2 & 59 & 3 & 227 & 3 & 104 \\
\hline Oesophagus & 4 & 84 & 1 & 47 & 2 & 48 \\
\hline Stomach and small intestine & 27 & 88 & 24 & 142 & 31 & 108 \\
\hline Large intestine & 10 & 60 & 6 & 81 & 13 & 88 \\
\hline Rectum & 15 & 164 & 7 & 153 & 10 & 129 \\
\hline Liver and biliary passages & 3 & 52 & 8 & $307^{\star}$ & 5 & 98 \\
\hline Pancreas & 6 & $43^{\star}$ & 1 & 18 & 13 & 110 \\
\hline Nose & 0 & - & 0 & - & 0 & - \\
\hline Larynx & 1 & 36 & 4 & 329 & 2 & 82 \\
\hline Trachea and lung & 107 & 87 & 62 & 129 & 104 & 100 \\
\hline Bone & 0 & - & 1 & 170 & 1 & 77 \\
\hline Connective tissue & 3 & 243 & 1 & 279 & 2 & 201 \\
\hline Skin & 6 & 192 & 0 & 0 & 4 & 155 \\
\hline Breast & 0 & - & 1 & 671 & 1 & 311 \\
\hline Prostate & 7 & 55 & 7 & 81 & 15 & 115 \\
\hline Genital organs & 2 & 87 & 0 & - & 4 & 169 \\
\hline Bladder & $1 \overline{1}$ & 66 & 7 & 98 & 20 & 137 \\
\hline Brain & 9 & 120 & 2 & 96 & 8 & 134 \\
\hline Thyroid gland & 1 & 133 & 1 & 353 & 1 & 154 \\
\hline Lymphatic glands & 0 & - & - & - & 0 & - \\
\hline Lymphoreticular sarcoma & 3 & 86 & 4 & 307 & 2 & 67 \\
\hline Hodgkin's disease & 2 & 49 & 1 & 104 & 6 & 186 \\
\hline Other lymphoma & 0 & - & 1 & 120 & 4 & 173 \\
\hline Multiple myeloma & 2 & 50 & 2 & 118 & 4 & 115 \\
\hline Leukaemia & 13 & 135 & 6 & 163 & 7 & 85 \\
\hline Benign neoplasms & 4 & 246 & 1 & 166 & 2 & 145 \\
\hline Not specified neoplasms & 19 & 140 & 7 & 124 & 11 & 94 \\
\hline Other & 2 & 47 & 2 & 115 & 7 & 187 \\
\hline Total & 893 & $90^{\star}$ & 520 & $118 \cdot 7^{\star}$ & 854 & 97 \\
\hline
\end{tabular}

${ }^{*} \mathrm{p}<0.05$ two sided.

cancer $($ SMR $=307,95 \%$ CI 132-2-604.9). The increased risk for liver cancer was significant. The SMR for respiratory cancer (lung cancer, and laryngeal cancer combined) was 133.9 (95\% CI 103.7170.6) and reached statistical significance. Coke oven workers of coke plant $M$ experienced the highest risk for mortality from lung cancer $(S M R=139)$, which approached statistical significance and mortality from respiratory diseases $(\mathrm{SMR}=166,95 \% \mathrm{CI}$ 116.6-235.4), which was significant.

Based on job descriptions the coke oven workers were classified as top workers or side oven workers. In the top workers the increased mortality from respiratory diseases $(\mathrm{SMR}=175,95 \%$ CI $106 \cdot 6-$ 269.7) was statistically significant. Mortality from liver cancer was also significantly increased (SMR = $664,95 \%$ CI $242 \cdot 6-1,446 \cdot 3)$. Side oven workers experienced a significantly increased risk for lung cancer $(S M R=141,95 \%$ CI 102.7-189.7) and gastric cancer $(S M R=172,95 \%$ CI 103.4-269.4). The increased risk for laryngeal cancer $(S M R=329)$ was not statistically significant. The cause specific death rates in the other departments of the coke plants were similar to the expected figures, with two exceptions. Workers in the tar distillery experienced a higher rate of lung cancer than expected (SMR = 154), and workers in the coke shipping department had higher mortality from gastric cancer $(S M R=$ 200) and non-malignant respiratory disease (SMR = 167). These, however, were not significantly different from 100 . Among the 222 former workers in the benzene plant no indication was found for the occurrence of an increased risk for leukaemia, but the expected number was small.

\section{Discussion and conclusions}

Dutch coke oven workers have experienced higher mortality for several diseases compared with controls. Death rates from lung cancer were $29 \%$ higher than in the general population if no correction was made for the healthy worker effect. Mortality from non-malignant respiratory diseases was $60 \%$ higher than that in the general population. Unfortunately in 
our study it was not possible to collect data on smoking habits and socioeconomic state of the individual workers. Therefore, it is possible that these factors may explain the results. Other investigators have argued, however, that the effect of not controlling for smoking tends to be small in most situations. $^{29}$ The findings in our study are in agreement with data from Great Britain, but are not consistent with the high risks found in the United States. One possible explanation is that exposure to carcinogens for United States coke oven workers may have been higher than in Great Britain. Personal air samples taken at United States and British coke ovens indicate that this is the case. The samples in the United States had an average of $2.25 \mathrm{mg} / \mathrm{m}^{3}$ of benzene soluble matter compared with $1.29 \mathrm{mg} / \mathrm{m}^{3}$ in Britain. Samples taken in a Dutch coke plant averaged $1.05 \mathrm{mg} / \mathrm{m}^{3}$ of benzene soluble matter. These samples were taken at a different coke plant, however, from those investigated in our study. The exposure in the coke ovens of the study presented here may have been higher, because they were not as modern as those in which the samples were taken. Two differences between American and European coke plants could be important regarding this issue, namely racial differences among the workers and the different working temperatures of the ovens. The American coke ovens have mainly been operated by non-white employees, who may be at higher risk of developing lung cancer than white workers, after prolonged exposure to coke oven emissions. American coke ovens have been heated to higher temperatures than many European ovens, as the main purpose of the American coke plants was to produce metallurgical coke; in Europe the byproducts were regarded as highly desirable. Also, the studies in the United States go further back in time $^{19-21}$ when exposures to polycyclic aromatic compounds may have been higher.

Other cancer risks noted in the United States were not seen although the excess of liver cancer is a reason for concern. It has been suggested that this might be related to a higher regional alcohol consumption but this finding has not been reported elsewhere and may be a matter of chance.

The study was supported by a grant from the Queen Wilhelmina Fund, a private Dutch cancer foundation. We thank the Central Bureau of Statistics for their cooperation in the project and for providing the causes of death for the workers in the study.

1 International Labour Office. Encyclopedia of Occupational Health and Safety, Geneva: ILO, 1983.

2 Wilson PJ, Wells JH. Coal coke, and coal chemicals. New York: McGraw-Hill Book Co, 1950.

3 Environmental Protection Agency. An assessment of the health effects of coke oven emissions. Washington, DC: Office of Research and Development, 1978.
4 Nesnow S, Tripett LL, Slaga TJ. Comparative tumor initiating activity of complex mixtures from environmental particulate emissions on SENCAR mouse skin. J Natl Cancer Inst 1982;68:829-34.

5 Nesnow S, Triplett LL, Slaga TJ. Mouse skin tumor initiationpromotion and complete carcinogenesis bioassays: Mechanisms and biological activities of emission samples. Environ Health Persp 1983;47:255-68.

6 Horton AW, Tye R, Stemmer KL. Experimental carcinogenesis of the lung. Inhalation of gaseous formaldehyde or an aerosol of coal tar by $\mathrm{C}_{3} \mathrm{H}$ mice. J Natl Cancer Inst 1963;30:31-43.

7 Tye R, Stemmer KL. Experimental carcinogenesis of the lung II. Influence of phenols in the production of carcinoma. J Natl Cancer Inst 1967;39:175-86.

8 International Agency for Research on Cancer. IARC monographs on the evaluation of the carcinogenic risk of chemicals to humans. Polynuclear aromatic compounds. Vol 34, Part 3. Industrial exposures in aluminium production, coal gasification, coke production and iron and steel founding. Lyon: IARC, 1984.

9 Kennaway EL, Kennaway NM. A further study of the incidence of cancer of the lung and larynx. Br J Cancer 1947;1:260-98.

10 Christian HA. Cancer of the lung in employees of a public utility. J Occup Med 1956;14:133-9.

11 Reid DD, Buck C. Cancer in coking plant workers. Br J Ind Med 1956;13:265-9.

12 Kawai M, Amamoto A, Harada K. Epidemiologic study of occupational lung cancer. Arch Environ Health 1967;14: 859-64.

13 Kuroda S, Kawahata K. Über die gewerbliche entstehung des Lungenkrebses bei Generatorgasarbeitern. Zeitschrift Krebsforschung 1936;45:36-9.

14 Doll R, Vessey MP, Beasley RWR, et al. Mortality of gasworkers. Final report of a prospective study. Br J Ind Med 1972;29:394-406.

15 Sakabe $\mathrm{H}$, Tsuchiya $\mathrm{K}$, Takekura $\mathrm{N}$, et al. Lung cancer among coke oven workers. Ind Health 1975;13:57-68.

16 Davies GM. A mortality study of coke oven workers in two South Sales integrated steelworks. Br J Ind Med 1977;34: 291-7.

17 Collings PL. Coke workers' mortality, a nine year follow-up in the British Steel Industry. Report prepared by the Statistics Branch, Institute of Occupational Medicine, Edinburgh, Scotland for the European Coal and Steel Community and the British Steel Corporation Edinburgh, 1978. (Report No TM/ 78/1.)

18 Hurley JF, Archibald R, Collings PL, Fanning DM, Jacobsen $M$, Steele RC. The mortality of coke workers in Britain. Am J Ind Med 1983;4:691-704.

19 Lloyd JW, Ciocco A. Long term mortality study of steelworkers. I Methodology. J Occup Med 1969;11:299-310.

20 Lloyd JW. Long term mortality study of steelworkers. V. Respiratory cancer in coke plant workers. J Occup Med 1971;13:53-68.

21 Redmond CKA, Ciocco JW. Long term mortality of steelworkers. IV. Mortality from malignant neoplasms among coke oven workers. J Occup Med 1972;14:621-9.

22 Redmond CKA, Wienand HS, Rockette HE, Sass R, Weinberg G. Long term mortality experience of steelworkers. Report prepared by the University of Pittsburgh, Pennsylvania, for NIOSH. Cincinnati, Ohio, 1979. (Contract No HSM-99-7132.)

23 Blot WJ, Brown LM, Pottern LM, Stone JB, Fraumeni JF. Lung cancer among long-term steel workers. Am J Epidemiol 1983;117:706-16.

24 Bertrand JP, Clau N, Patris A, Mur JM, et al. Mortality due to respiratory cancers in the coke oven plants of the Lorraine coal mining industry. Br J Ind Med 1987;44:559-65.

25 Merx HJ. Chronologisch overzicht van de geschiedenis van de cokesfabrieken en het gasdistributiebedrijf, 1912-1952. Geleen, the Netherlands: DSM Chemical Co, 1955.

26 Waes van JPM, Quanjel HE. The new "Emma" coking plant of the Netherlands State Mines. Coke and Gas 1956:83-7.

27 Peto J. Manyears: A program for computing observed and expected deaths or incidence rates. Oxford: International Publication, ICRF Cancer Unit, 1980.

28 Breslow NE, Day NE. Statistical methods in cancer research. II. The design and analyss of cohort studies. Lyon: International Agency for Research on Cancer, 1987.

29 Axelson O, Steenland $\mathrm{K}$. Indirect methods of assessing the effects of tobacco use in occupational studies. Am J Ind Med 1988;13:105-18.

Accepted 23 July 1990 